\title{
非セミノーマ性成人睪丸腫瘍の治療成績
}

$\begin{array}{lllll} & \text { 西 } & \text { 尾 } & \text { 恭 } & \text { 規 } \\ \text { 国立がんセンター病院泌尿器科 } & \text { 松 } & \text { 本 } & \text { 恵 } & \text { 一 } \\ & \text { 大 } & \text { 谷 } & \text { 幹 } & \text { 伸 } \\ & \text { 垣 } & \text { 添 } & \text { 忠 } & \text { 生 }\end{array}$

\section{RESULTS OF TREATMENT FOR ADULT NON-SEMINOMATOUS TESTICULAR CANCER}

\author{
Yasunori Nishio, Keiichi Matsumoto, Mikinobu Ohtani and Tadao Kakizoe \\ Department of Urology, National Cancer Center Hospital, Tokyo
}

Eighty-three cases of adult non-seminomatous testicular cancer were treated at the Department of Urology, National Cancer Center Hospital, Tokyo, from 1962 to August, 1984.

The three year survival rate was $100 \%$ for Stage I and IIa (8 cases), $0 \%$ for Stage IIb ( 2 cases) and $25.9 \%$ for Stage III (13 cases) from 1978 to 1984 , whereas it was $49.8 \%$ for Stage I ( 29 cases), $0 \%$ for Stage IIa ( 2 cases), $25 \%$ for Stage IIb ( 8 cases) and 4.8\% Stage III (21 cases) before 1978 .

Improvement of the survival rates after 1978 are due to the development of accurate staging methods such as tumor marker, CT-scan and ultrasonography and effective chemotherapy.

However, of 13 cases of Stage III from 1978 to 1984, only 1 patient had complete remission by chemotherapy. Therefore, cytoreductive surgery after chemotherapy appears essential for successful management of stage III testicular cancer.

要旨：1962年より1984年 8 月をでに83例の成人非セミノーマ性粹丸腫瘍を経験した。

病期別では, Stage I 35例, Stage IIa 4 例, Stage IIb 10例, Stage III 34例で, 組織学的分類では, 単一組織型34例 (Embrynal carcinoma 19例, Teratocarcinoma 9例, Choriocarcinoma 6 例), 複 合組織型49例 (Choriocarcinoma + any other types 20例, Embryonal carcinoma + teratocarcinoma 14例, other combinations 15例) であった.

各病期別 3 年実測生存率は, 1978年以前の症例では, Stage I 29例, 49.8\%, Stage IIa 2 例 $0 \%$, Stage IIb 8 例 $25 \%$, Stage III 21例4.8\%に対し，1978年以後の症例では, Stage I 6 例100\%, Stage IIa 2 例 $100 \%$, Stage IIb 2 例 $0 \%$, Stage III 13例 $25.9 \%$ と1978年以降の症例で治療成績の向上がみられた.

これは, 腫瘍マーカーの検索, CT-scan 超音波断層法の導入による診断技術の向上と CDDP を含む有 効な化学療法の出現に由来するものと考学られた.

しかし，1978年以降の Stage III 症例でも化学療法のみで治癒可能な症例は，13例中 1 例（7.7\%）の みで, 予後の向上の為には, 集学的治療, 特に, 残存腫瘍に対する積極的な手術療法が必須であると考 えられた。

\section{緒言}

従来きわめて予後不良であった非セミノーマ性粹丸 腫瘍も，化学療法の発達により治癒可能になってきて いる。しかし, 各組織型, 病期に㧊ける治療法の選択 には，さまざまな意見があり，手術療法，放射線療法， 化学療法の適応を明確にする必要がある。今回, 我々 は, 国立がんセンター病院で治療をうけた 83 例の成人
非セミノーマ性睪丸腫瘍の治療成績を検討したので報 告する.

\section{対象および方法}

1962年より1984年 8 月屯での 22 年間に国立がんセン タ一病院で治療をらけた精上皮由来の醉丸腫瘍症例の らち, 成熟奇形腫を除く成人非セミノーマ症例，83例 を対象とした。 
組織学的分類および病期分類は, 日本泌尿器科学会, 日本病理学会による睪丸腫瘍取扱い規約1)にしたがっ た.

病期分類は，除囯術時の病期を用いた。

予後の算出の起点は除辠術日とし，1984年 8 月31日 現在の成績である。

\section{1. 統計的事項}

\section{結＼cjkstart果}

対象症例の年齢は, 18 歳から 77 歳で，平均 30.9 歳で あった。

患側は，右34例，左49例で，左右に有意差はなかっ た。また，両側発生は認めなかった。停留辠丸に発生 したと考えられる症例も認めなかった。

病期分類招よび組織学的分類を Table 1に示す。病 期別では, Stage I 35例, Stage IIa 4 例, Stage IIb 10例，Stage III 34例であった。組織学的分類では，単 一組織型34例，複合組織型49例であった，単一組織型 では, Embryonal carcinoma が19例と最も多く, 次い で, Teratocarcinoma 9 例, Choriocarcinoma 6 例 であった。複合組織型では, Choriocarcinoma + any other types が20例と最も多く, Embryonal carcinoma + teratoma (teratocarcinoma) 14例, other combinations 15例であった。組織型と病期との関係に 扣いては一定の傾向を示さなかった。

\section{2. 治療成績}

当センターにCDDP が導入され，又，診断に腫瘍 マーカー, CT-scan, 超音波断層法が用いられるように なった1978年をさかいに以前と以後の治療成績を検討 すると，1978年以前の症例60例の各病期別実測 3 年生 存率が, Stage I 29 例 $49.8 \%$, Stage IIa 2 例 $0 \%$, Stage IIb 8 例 $25 \%$, Stage III 21例4.8\%に対し, 1978 年以後の 23 例では, Stage I 6 例 $100 \%$, Stage IIa 2

Table 1 Adult Non-Seminomatous Testicular Cancers.

1962 1984. August, N.C.C.H.

\begin{tabular}{cccccccc}
$\begin{array}{c}\text { Shistological } \\
\text { Stage pattern }\end{array}$ & E.* $^{* 1}$ & T.* $^{* 2}$ & C.3 $^{* *}$ & C.+Other. & E. T. & Others. \\
\hline I & 35 & 6 & 4 & 1 & 10 & 6 & 8 \\
II a & 4 & 1 & 2 & - & - & 1 & - \\
IIb & 10 & 3 & 1 & - & 2 & - & 4 \\
III & 34 & 9 & 2 & 5 & 8 & 7 & 3 \\
\hline Total & 83 & 19 & 9 & 6 & 20 & 14 & 15
\end{tabular}

例 $100 \%$, Stage IIb 2 例 $0 \%$, Stage III 13 例 $25.9 \%$ と1978年以後の症例で治療成績の向上が認められた (Fig. 1).

（1） Stage I の治療

Stage I 症例は35例であった. Stage I の診断は, 1978 年以前の症例では，リンパ管造影，排泄性腎孟造影， 胸部 X-P，肝シンチグラフィーによりなされたが，以 後の症例では，それらに加光，腫瘍マーカー，胸部・ 腹部 CT-scan，超音波断層法を施行した。1978年以前 の症例は 29 例, 以後の症例は 6 例であった。除䁄術後 の治療法と再発の有無を1978年以前と以後の症例で検 討すると Table 2の如くであった。1978年以前の症例

Fig. 1 Actuarial Survival Rates of Nonseminomatous Testicular Cancer Patients Relative to Stages.

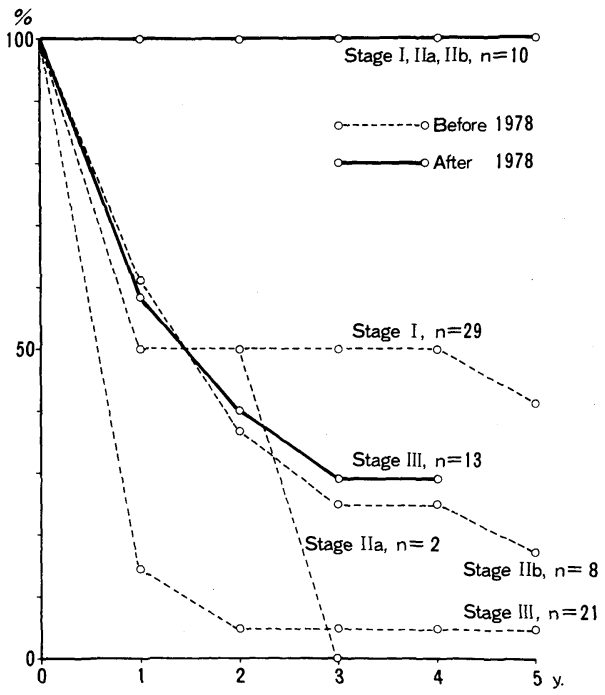

Table 2 Treatment and Recurrence of Stage I Non-Seminomatous Testicular Patients.

\begin{tabular}{l|ccc|ccc}
\hline & \multicolumn{3}{|c|}{$\begin{array}{c}\text { Before 1978 } \\
\text { Recurrence }\end{array}$} & \multicolumn{4}{c}{$\begin{array}{c}\text { After 1978 } \\
\text { Recurrence }\end{array}$} \\
& No. of Pts. & $(-)$ & $(+)$ & No. of Pts. & $(-)$ & $(+)$ \\
\hline Radiation & 16 & 3 & 13 & 3 & 3 & - \\
RPLND* & - & - & - & 1 & - & 1 \\
$\begin{array}{c}\text { Radiation }+ \\
\text { RPLND }\end{array}$ & 5 & 4 & 1 & - & - & - \\
Chemotherapy & 3 & - & 3 & 1 & 1 & - \\
None & 5 & - & 5 & 1 & 1 & - \\
\hline Total & 29 & 7 & 22 & 6 & 5 & 1
\end{tabular}

RPLND* ; Retroperitoneal Lymph Nodes Dissection. 
では, いずれの治療法に於いても, 再発率が高く, 全 体として，29例中22例 (76\%) に再発を認めた。 また， 再発部位の検討では, 22例中17例に肺転移を認めた。

予後の関係では, 29 例中再発を認めなかった 7 例は全 例生存中であるが，再発をきたした22例の予後は不良 で， 3 例が生存しているが，19例は腫瘍死した。再発 後, 救命しえた 3 例中 2 例は, 肺に独立性転移をさた した症例で, 手術療法にて摘出しえた。他の 1 例は, 左鎖骨上窝リンパ節, 肺に多発性転移を認めたが，鎖 骨上窩リンパ節に40Gy の放射線療法と Act-D, BLM, Leucovorin を併用した MTX の大量療法により転移 栄の消失をみた。

以上, 1978 年以前の症例の予後は不良で, 29例中 10 例が生存, 19例が腫瘍死した。

1978年以降の症例 6 例の治療法は, 放射線療法 3 例, 後腹膜リンパ節郭清術（以下 RPLND） 1 例, 化学療 法 (CDDP + VBL + BLM (以下 PVB) - 2course) 1 例, None 1 例で, 再発をきたした症例は, RPLND 後 に肺転移を認めた 1 例（17\%）のみであった。

6 例の予後は良好で, 5 例が再発なく生存しており, 再発した 1 例も右肺摘除術, 術後の化学療法 (PVB-2 course CDDP+IFO）にて治癒し，全例が生存中であ る.

\section{（2） Stage IIa の治療}

Stage IIa の症例は 4 例であった. Stage 診断は1978 年以前の 2 例は RPLND によりなされ, 78年以降の 2 例中， 1 例は腫瘍マーカーの消長により，1例はCT. scan, 超音波断層法によりなされた。

1978年以前の 2 例中, 1 例は RPLND 後, stress gastric ulcerの穿孔をきたし, 沉性腹膜炎にて死亡, 剖検にて癌の再発転移を認めなかった。他の 1 例は, RPLND 後, 放射線療法を $8.5 \mathrm{~Gy}$ 施行した時点で治療 を拒否し，以後通院なく調查にて死亡を確認した。

1978年以後の 2 例中, 1 例はCT-scan, リンパ管造 影, 超音波断層法にてる転移巣は描出されなかったが, 除辠術後の AFP の下降より, リンパ節転移を有する と判断し, PVB 療法を 1 コース施行後, RPLNDを施 行した。 2 個の転移巣を認め, 組織診断は mature teratoma であった. 術後, PVB療法を1コース施行, さ らに CDDP + IFO による維持療法を $1 / 3 \mathrm{M} て ゙ ~ 5$ コース 施行. 現在 2 年 8 力月であるが, No evidence of disease(以下 NED) で健在である. 今の 1 例は, CT-scan, 超音波断層法で後腹膜リンパ節に転移を認め, 全骨 盤十傍大動脈リンパ節に $50 \mathrm{~Gy}$ の放射線療法を施行,
Table 3 Cases of Stage IIb Non-Seminomatous Testicular Cancer

\begin{tabular}{|c|c|c|c|c|c|c|}
\hline \multirow[b]{2}{*}{ Case } & \multirow[b]{2}{*}{ Age } & \multirow[b]{2}{*}{ Histology } & \multicolumn{3}{|c|}{ Treatment } & \multirow{2}{*}{ Prognosis } \\
\hline & & & Radiation & Operation & Chemotherapy & \\
\hline 1 & 32 & $E+S$ & $(+)$ & Lapa. & $(-)$ & 12y10M, Alive \\
\hline 2 & 35 & $E$ & $(+)$ & $\begin{array}{l}\text { RPLND + } \\
\text { Lt-nephrectomy }\end{array}$ & $E x+V C R$ & 2 y $7 \mathrm{M}$, Dead \\
\hline 3 & 24 & $E+S$ & $(+)$ & Lapa. & $(-)$ & $2 \mathrm{M}, \quad "$ \\
\hline 4 & 37 & $E$ & $(t)$ & Lapa. & $\begin{array}{l}\text { Ex+VCR, Act-D, } \\
\text { BLM }\end{array}$ & 1 y $2 M, "$ \\
\hline 5 & 31 & $c+s$ & $(+)$ & $(-)$ & VCR, ACNU, ADR & $9 \mathrm{M}, \quad "$ \\
\hline 6 & 45 & $T$ & $(+)$ & $(-)$ & $\begin{array}{l}\text { Ex+MMC, } \\
\text { Ex+VCR+MTX }\end{array}$ & $|y| M, "$ \\
\hline 7 & 27 & $E$ & $(t)$ & $(-)$ & MMC & $3 \mathrm{M}_{1} \quad 1$ \\
\hline 8 & 37 & $C+E$ & $(-)$ & RPLND & $M M C+E x+5 F U$ & 4 у $2 M, " ~$ \\
\hline 9 & 26 & $E+S$ & $(-)$ & RPLND & PVB-1) & $4 \mathrm{M}$, Alive \\
\hline 10 & 43 & $T+E+S$ & $(-)$ & RPLND & $\begin{array}{l}C D D P, C D D P+V B L \\
C D D P+V P-16\end{array}$ & $10 \mathrm{M}, " 1$ \\
\hline
\end{tabular}

転移巣の縮小をみたが 4 カ月後に多発性肺転移が出 現，PVB 療法 3 コース施行し完全寛解（以下 CR）に 至った。現在 $\mathrm{CR}$ 後 1 年 1 力月であるが NED にて健 在である.

（3） Stage IIb の治療

Stage IIb の症例は10例であった(Table 3). 1978年 以前の症例は 8 例（Case 1 8). 1978年以降の症例は 2 例 (Case 9,10) である。1978年以前の治療は，放射 線療法を中心に後腹膜リンパ節廓清術を施行する方針 であった。放射線療法を施行した 7 例中，リンパ節廓 清術を施行し得た症例は 1 例のみで， 3 例は開腹術と 生検に終わり，残り 3 例は血行性転移をきたし化学療 法に方針を变更した。予後との関係をみると，放射線 療法後開腹術生検に拉わった 1 例（Care 1）に追加照 射し CR を得ているが, 他の 6 例は, 1 例が開腹術後の 術死により死亡, 5 例はいずれも血行性転移をきたし， 化学療法㓮として Ex, VCR, ADR, 5FU, MMC, $\mathrm{ACNU}, \mathrm{BLM}$ を単剂あるいは多剂併用療法で用いた が，CR に至った症例はなく死亡している. RPLNDを 第 1 選択とした 1 例（Case 8）は, RPLND 後 3 年 6 カ月で局所再発をきたし， MMC $+\mathrm{Ex}+5 \mathrm{FU}$ をいた が Progressive disease (以下 PD) にて死亡した.

1978年以後の症例は 2 例である (Case 9, 10). Case 9は術前化学療法としてPVB療法を 1 コース施行後 RPLND を施行, 組織診断は Grade IV-A radiochange (大星, 下里の分類 $\left.{ }^{2}\right)$ であった。 PVBによる術後 化学療法を予定したが創部感染のため中止, 現在 NED てて経過観察中である. Case 10は, CDDP, $\mathrm{CDDP}+\mathrm{VBL}$ の投与後, RPLNDを施行, 組織診断は Grade II-A radiochange で viable cell を認めたため, 術後化学療法として CDDP+VP-16を採用した。現在, 
RPLND 後 2 カ月であるが NED である.

（3） Stage III の治療

Stage III の症例は34例であった. 1978年以前の症例 21例に対しては，放射線療法，化学療法を種々の組み 合わせで施行した。しかし，予後は不良で生存例は 1 例のみで, 残り 20 例はいずれも除辠術後 1 年 6 力月以 内に死亡している.

生存例は27歳, 左粹丸に発生した Embryonal carcinoma の症例で除辠術時, 胸部 X-P にて両肺に多発 性転移を, リンパ管造影にて後腹膜リンパ節に転移巣 を認めた. Futraful 800mg/day を内服し, 全骨盤十傍 大動脈リンパ節に $21 \mathrm{~Gy}$ の放射線療法を施行, さらに, Ex 500mg と VCR 2mg の毎週交互の投与による化学 療法を 2 年間施行した。後腹膜リンパ節転移巣揖よび 肺転移巣は, 放射線療法後 4 力月で $\mathrm{Ex}+\mathrm{VCR}$ 投与開 始後 3 カ月で完全消失し以後再発を認めず, 現在, 除 鼻術後 12 年 7 カ月であるが健在である.

1978年以後の 13 例に対しては, 第一選択として化学 療法を採用した。初回の化学療法の Regimen として, 5 例に Eastern-Co-operative Oncology Group の regimen ${ }^{3)}$ による VCR+Act-BLM (以下 VAB 療法) を, 8 例に Einhorn らによる Regimen ${ }^{4}, \mathrm{CDDP}+$ $\mathrm{VBL}+\mathrm{BLM}$ (PVB 療法) を用いた。化学療法に対す る効果は VAB 療法では $\mathrm{CR}$ が 0 例, 部分的寛解(以下 PR) が 4 例, No change (以下 NC) が 1 例で CR に 至った症例はなかった. PVB 療法では, $\mathrm{CR} 1$ 例, PR 6 例, NC 1 例であった.

$\mathrm{VAB}$ 療法を第 1 選択とした 5 例中 NCであった 1 例は後療法を施行できぬまま死亡したが，PR を示し た 4 例にはさらにCDDPを含む化学療法 (CDDP+ IFO 2 例, PVB 1 例, CDDP+Ex 1 例), 残存腫瘍 に対する放射線療法を施行した。しかし，CR に至った 症例はなく全例が 2 年以内に腫瘍死した。

PVB 療法を第 1 選択とした 8 例中, $\mathrm{CR}$ を示した 1 例は, その後, 再発転移の徴候を認めず, 現在, 除辠 術後 3 年 5 力月, NED 後 3 年であるが，健在である. $\mathrm{PR}, \mathrm{NC}$ であった 7 例中 3 例に残存腫瘍に対する手術 療法を施行した。PR 1 例揖よび NCの 1 例は腫瘍が 摘出可能で NED に達した. 現在, NED 後 3 年 4 カ月 であるが再発転移の徵候なく健在である，PR であっ た 1 例は手術療法にても NED に至らず, CDDPを含 む化学療法, 再度の手術療法, 放射線療法を施行した が CR には至らず腫瘍死した。

PR であった 6 例中，手術療法を施行しなかった 4
例中 1 例は残存腫瘍に対する手術療法を予定して現在 入院中である. 3 例は, 放射線療法, 化学療法 (MTX, Act-D，CDDP+VP-16）を施行したが NED には至ら ず腫瘍死した。

以上, 1978年以後の Stage III 症例のうち, VAB, PVB 療法で CR に至った症例は13例中 1 例のみで, PR 10例，NC 2 例であった. PR, NC症例のらち手 術療法を施行しなかった 9 例中 8 例は死亡している （1例は手術療法を予定している）ことより残存腫瘍に 対する手術療法は予後の向上のためには必須のことと 考えられる。ここで, 手術療法を施行した 3 例の臨床 経過を示す。

症例 1. 32歳, 調理師。

初診：1981年 3 月 31 日.

主訴: 左辠丸の腫脹, 腰痛.

現病歴抒よび治療経過 (Fig. 2).

1980年12月より腰痛, 左辠丸の腫脹に気づくも放置 していた。1981年 2 月 12 日, 腰痛増悪のため某病院整 形外科受診, 左辠丸腫瘍, 後腫膜リンパ節転移, 左鎖 骨上窩リンパ節転移の診断のもとに, 同日同院泌尿器 科入院となる， 2 月 12 日左高位除辠術を受け，病理診 断は Teratocarcinoma であった。術前, AFP 1,029ng, $\beta$-HCG 34.8ng と高値を示した.

排泄性腎孟造影で左腎は水腎症を呈し，尿管は左方 に扁位していた.CT で $13 \times 12 \mathrm{~cm}$ の腫瘍を左後腹膜腔 に認めた。触診にて左鎖骨上窩に直径 $2 \mathrm{~cm}$ 大の可動性 のある腫瘍を 2 個触知した。胸部 X-P で肺転移巣は認 めなかった（Stage IIIa）.

術後, 腹部腫瘍に対し22.5Gy の放射線療法を受け, 3 月16日より CDDP $+\mathrm{VBL}+$ Pepleomycin の化学療 法を 1 コース受けた。 3 月 31 日当センター初診, 4 月 6 日より 9 月 13 日まで入院した。 4 月 20 日より 24 日ま で, CDDP $17 \mathrm{mg} \times 5+$ IFO $2 \mathrm{~g} \times 5+\mathrm{VBL} 12 \mathrm{mg} \times 2+$ $\mathrm{MTX} 15 \mathrm{mg} \times 1 ， 5$ 月18日より24日まで CDDP 85 $\mathrm{mg}+\mathrm{IFO} 10 \mathrm{~g}+\mathrm{VBL} 24 \mathrm{mg}$ の化学療法を施行した.

3 コースの化学療法にて血清 AFP, 血清 $\beta$-HCG は 正常化した。しかし, 触診, 扣よび超音波断層検査, CT-scan にて，左鎖骨上窩リンパ節，後腹膜リンパ節 転移巣の縮少は認めなかった（NC）.

化学療法による治療は無効と判断し, 残存腫瘍に対 する手術療法を施行した。

1981年 6 月 24 日, 後腹膜転移腫瘍を含む RPLNDを 施行, 腫瘍と大血管との剥離は比較的容易であったが 左腎の合併切除を必要とした. Bulky tumor の他に左 
Fig. 2 Case-1. 33y.o. Teratocarcinoma.

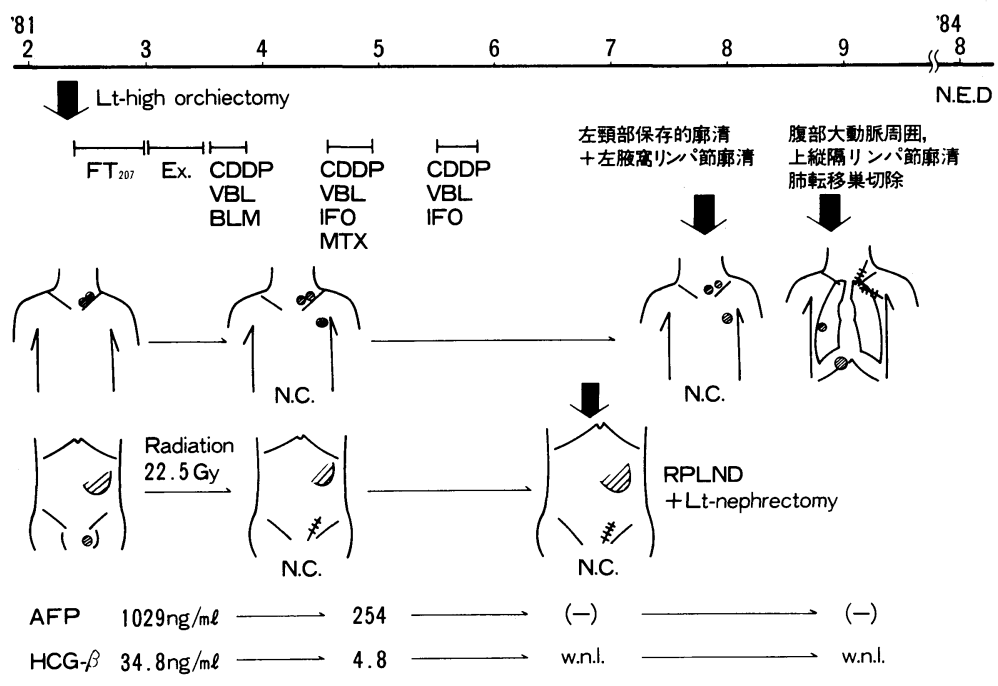

内腸骨動脈にそって直径 $2 \sim 3 \mathrm{~cm}$ の 4 個の腫瘍を認め 摘出した。病理診断は, 95\%以上はよく成熟したTeratomaで部分的に未熟な間葉系細胞群を伴 5 Teratocarcinoma であった。

7 月23日, 左䅡部保存的廓清術および左腋窩リンパ 節廓清術を施行, 左鎖骨上窩リンパ節転移巣を摘出し た. 術前触知した腫瘍は 2 個であったが鎖骨より左腋 窩にかけ計34個の転移巣を認めた。しかし, 周囲の剝 離は容易であった。病理診断は極く一部に未熟な間葉 系細胞を認めたが, 大部分はよく成熟した Teratocar- cinoma であった.

術後の CT-scan で, 横隔膜直上, 腹部大動脈と下大 静脈の間で直径 $2 \mathrm{~cm}$ の転移巣を認めた。 8 月28日，右 開胸にて胸腔内に入り, 転移巣を摘出, さらに上縦隔 リンパ節を廓清した. 右肺を触診した際, 直径 $5 \mathrm{~mm} の$ 転移巣を触知し腫瘍を含め右肺下葉を部分切除した。 病理診断は，腹部大動脈リンパ節，肺転移巣はいずれ も mature teratoma であった. 上縦隔リンパ節には転 移を認めなかった。術後経過は良好にて 9 月 13 日退院 した。以後，外来にて経過観察中であるが再発転移の

Fig. 3 Case-2. 23y.o. Embryonal carcinoma+Teratocarcinoma.

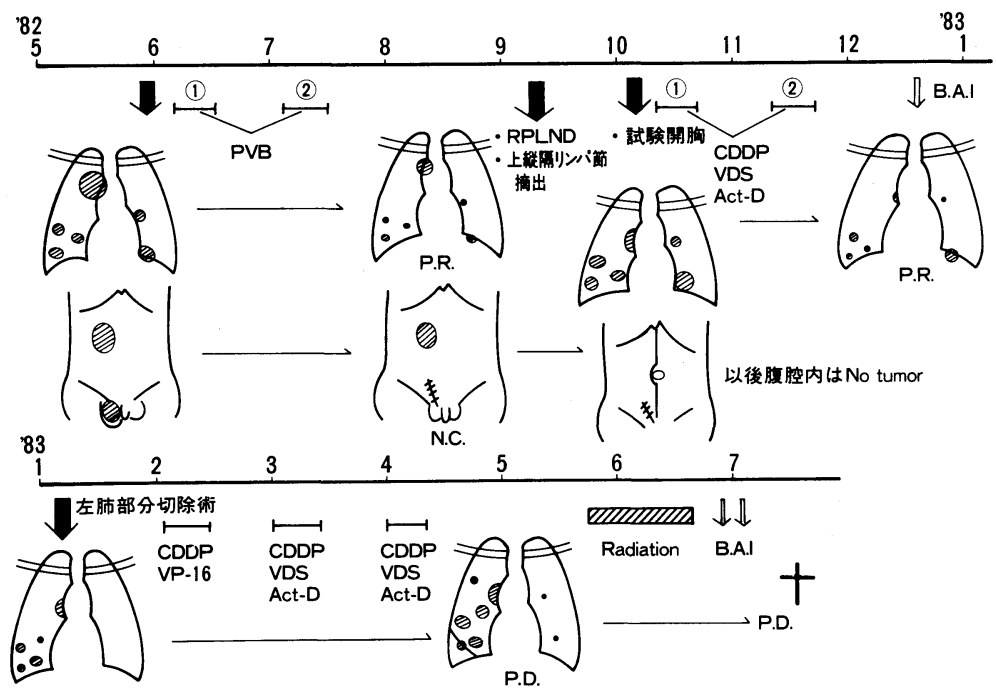


徵候は認めず，健在である。

症例 2.23 歳, 学生.

初診：1982年 5 月 24 日.

主訴：左峝丸の腫脹, 咳, 胸痛。

現病歴执よび治療経過 (Fig. 3).

1978年 9 月頃より右辠丸の無痛性腫脹に気づくも放 置していた．1982年 3 月より咳，胸痛が出現，4 月の 学校検診にて胸部の異常陰影を指摘され，5月24日当 センターに初診, 初診時右睪丸は小児頭大に腫大, 右 季肋部に手挙大の腫瘍を触知, 胸部 X-P にて多発性の 肺転移，上縱隔リンパ節転移を認めた。血清の AFP $838 \mathrm{ng} / \mathrm{ml}, \mathrm{LDH} 1,634 \mathrm{mu} / \mathrm{ml}$ と高值を示したが尿中 HCG，血清 $\beta$-HCG は正常であった。1982年 5 月28日 上り入院， 6 月 2 日右高位除辡術を施行，右辠丸重量 $1,000 \mathrm{~g}$, 病理診断は Embryonal carcinoma with teratomaであった。1982年 6 月10日より PVB 療法を 2 コース施行, 後腹膜転移巣の大きさに変化を認めず, 肺転移巣，上緃隔リンパ節転移巣は $50 \%$ 以上縮少した (PR). 血清 LDH は正常化するも血清 AFP は31ng/ $\mathrm{ml}$ と陰性化しなかった。9 9 月 1 日, 後腹膜腫場を含む RPLND および上緃隔リンパ節転移巣摘出術を施行し た。病理診断は後腹膜転移巣は Teratocarcinoma, 上 縦隔リンパ節転移巣は Embryonal carcinoma であっ た. 10 月 4 日, 両肺転移巣の摘出を目的とし, 右開胸 にて胸腔内に至るも肺門部リンパ節の腫大，両肺に無 数の転移巣を認め, 摘出不能と判断, 試験開胸にて閉 胸した. 術後腫瘍の増大による急速に増悪する呼吸困 難を生じ, 10 月 13 日より CDDP $25 \mathrm{mg} \times 5+$ ビンデシン
$3 \mathrm{mg} \times 2+$ Act-D 0.5mg $\times 5$ による化学療法を 4 週間毎 に 2 コース施行. X-P, CT-scan 上肺転移巣は $50 \%$ 以上 縮小した $(P R) .1982$ 年12月10日, 左右の気管支動脈上 り CDDP 100mg 注入，全身的に CDDP の中和剤であ るチオ硫酸ソーダを静注した。血管豊富な肺門部の腫 瘍の縮小をみたが，末梢部の腫瘍の大ささは変わらな かった. 1983年 1 月 9 日, 左肺転移巣 2 個を摘出した。 病理診断は Embryonal carcinoma であった。 1983年 2 月 2 日より 6 日まで, $\mathrm{CDDP} 25 \mathrm{mg} \times 5+\mathrm{VP}-16150$ $\mathrm{mg} \times 5,3$ 月 2 日から 6 日, 4 月 5 日から 9 日と, $\mathrm{CDDP} \quad 25 \mathrm{mg} \times 5+$ ビンデシン $3 \mathrm{mg} \times 2+$ Act-D 0.5 $\mathrm{mg} \times 5$ による化学療法 2 コースを施行, いずれの化学 療法も一時的な AFP の下降, 腫瘍の縮小傾向を示す も，その効果の持続期間は 3 週間であった(PD). 5 月 13日より肺転移巣に対し，1回10～12Gy の Spotirradiationを施行, 照射部位の腫瘍は縮小寸るも, 他 部位に新たな転移巣が出現，1983年 7 月16日呼吸不全 のため死亡した．剖検にて両肺，胸膜，絽隔リンパ節 に多数の転移を認めたが腹腔内転移はなかった。組織 学的に転移巣はすべて Embryonal carcinoma であっ た。

症例 $3 ： 28$ 歳, 事務系会社員。

初診：1984年 1 月 19 日.

主訴：左首丸の腫脹, 腰痛。

現病歴および治療経過 (Fig. 4).

1983年 5 月より左鼻丸の腫脹に気づくも放置してい た. 12月になり腰痛出現, 近医受診, 胸部 X-P にて 2 個の coin-lesion を指摘. DIP にて左無機能腎であっ

Fig. 4 Case-3. 28y.o. Embryonal carcinoma+Seminoma.

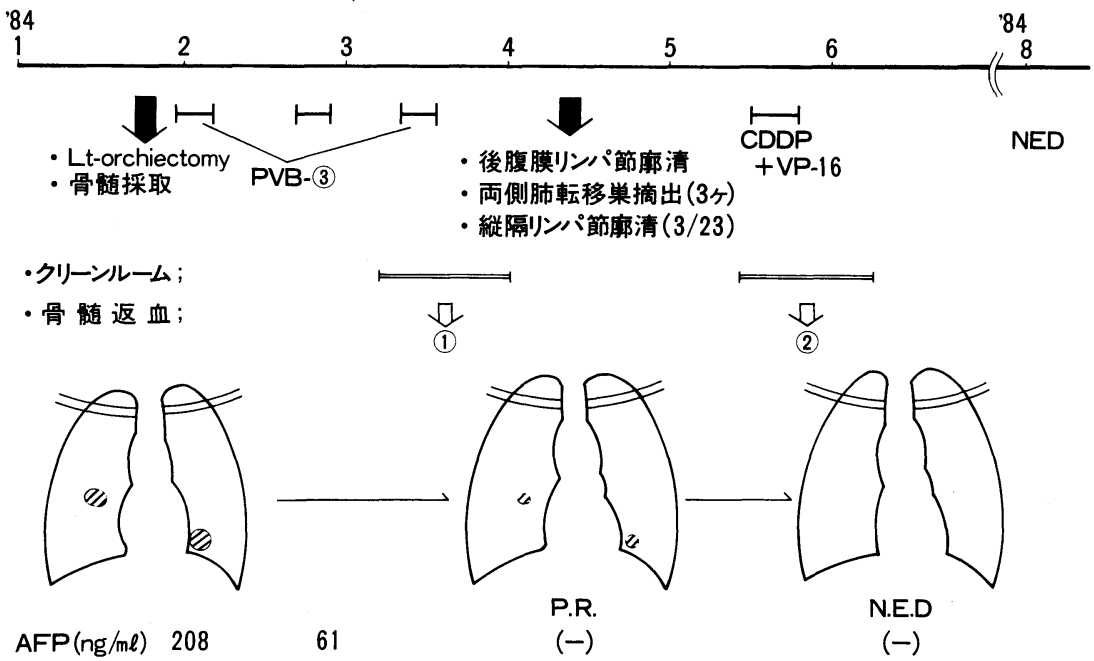


た。 1984 年 1 月 19 日当センター初診，初診時左辠丸は 超䳕卵大に腫大，胸部 X-P にて右肺に $16 \times 15 ， 36 \times 33$ $\mathrm{mm}$ の coin-lesion を認めた。 血清 AFP $208 \mathrm{ng} / \mathrm{ml}$, $\mathrm{LDH} 1,194 \mathrm{mu} / \mathrm{ml}$, 血清 $\beta$-HCG $3.49 \mathrm{ng} / \mathrm{ml}$, 尿中 HCG $1,000 \mathrm{IU} / \mathrm{L}$ といずれも高值を示した。 入院後の DIP では異常を認めず腰痛も消失していた。1984年 1 月23日入院，1月26日全麻下に左高位除辠術，両側腸 骨より骨髄採取術を施行した。左粹丸重量 $60 \mathrm{~g}$, 病理診 断は Embryonal carcinoma+Seminoma であった。 1 月 28 日より 3 月 16 日まで PVB 療法 3 コース施行, 3 月19日骨髄を返血した。血清 AFP, $\beta$-HCG, LDH, 尿中 HCG はいずれも 1 コース終了後より正常化した が,肺転移巣は $8 \times 5,11 \times 12 \mathrm{~mm}$ と縮小するも消失には 至らなかった $(\mathrm{PR}) .4$ 月 11 日, RPLND および縱隔り ンパ節廓清術, 肺転移巣摘出術を施行した。胸部 X-P 上認められた転移巣は 2 個であったが開胸時, 肺の触 診では 3 個の転移巣を認め切除した。病理診断で後腹 膜リンパ節に転移を認めず $(0 / 15)$, 縦隔リンパ節に 3 個の転移巣 $(3 / 23)$, 肺転移巣 3 個を認めた。組織学的 検索では転移巣はいずれも necrosisに陥っていた (Grade IV-A radiochange), 術後経過良好にて 5 月 15 日より 5 月19日まで CDDP $25 \mathrm{mg} \times 5+\mathrm{VP}-16160$ $\mathrm{mg} \times 5$ の化学療法を施行, 5 月21日骨髄を返血した。 6 月 10 日退院, 現在 NED にて外来で経過観察中であ る.

\section{考 察}

最近の化学療法の進歩, 各種腫瘍マーカーの検索, CT-scan, 超音波断層法の出現などの病期診断技術の 向上により, 辠丸腫瘍の診断・治療の考方方が従来と はだいぶ異なってきて抢り, 組織型, 病期による治療 方針の検討が必要となっている。

組織型別による分類については，従来より seminomaは, 他の組織型より放射線感受性が高く, 蚟 丸腫瘍を seminoma と non-seminoma に大別して論 じられている。事実, Stage I, IIaの seminomaは, 後腹膜リンパ節への放射線療法にて, 100\%近い治癒が 得られており, 治療法が確立されている5). しかし， Stage IIb 以上の進行性 seminoma では放射線療法で 治癒させることはむずかしく, 進行例では, 化学療法 を first-choice にすべきであり, non-seminoma と同じ regimenで良好な成績が得られたといら報告があ $ろ^{6)}$.

当センターの検討でも, Stage I, IIa の seminoma は, 後腹膜リンパ節への放射線療法にて $100 \%$ 治癒率
を得られたのに対し, Stage IIb 以上の症例では, 放射 線療法のみでは治癒はむずかしく, CDDPを含む化学 療法を first-choice にし，残存腫瘍に対する積極的な 手術療法が必要であると考えている7).

Non-seminoma の中でも, choriocarcinoma と他の 組織型では予後が異なり, HCG 陽性例は, HCG 陰性 例と区別して治療方針を考光るべきだとする意見もあ $3^{8) 9)}$

今回の集計では，83例中， choriocarcinoma を含む 症例は26例，含まない症例は57例であったが（Table 1), 両者間に病期, 治療に対する効果, 予後に関して 明らかな差異を認めなかった。 ただ，大部分の症例が 1978年以前の, 有効な化学療法, 診断技術の向上が出 現する以前の症例であるため, 現時点での治療法に対 する効果に，両者間に差異があるかは不明であり，今 後検討すべき課題であろう.

次に各病期別診断・治療につき考察を加えたい.

Stage I について

Stage I と診断する上には, 臨床的に転移がないこと を確認しなければならない。

以前はリンパ管造影, 排泄性腎孟造影, 胸部 X-P, 胸 部断層撮影, 肝シンチグラムにより診断がなされてい たが, 近年, 腫瘍マーカーの測定, CT-scan, 超音波断 層法が加わり，より正確な診断がなされるようになっ てきた。

今回の検討では, 各種マーカー, CT-scan, 超音波断 層法が診断に応用される1978年以前の症例29例中, 22 例に再発を認めたのに対し，1978年以後の 6 例では 1 例に再発を認めたのみで, 再発率が低下している。 Stage I に対する高位除辡術後の後療法が1978年前後 で差異がないことより，この再発率の低下は，病期診 断技術の向上によることが大きいと考えている.

Stage I 症例の高位除䁄術後の治療法については 様々な意見があり，いまだに統一されたものはない。 現在まで施行されてきた主な後療法は後腹膜リンパ節 廓清術と後腹膜リンパ節への放射線療法であり, 最近 になり, 厳重な follow up のみで後療法は施行しない といら意見も出てきている。

RPLND は, 臨床的に Stage I と診断された症例の より確実な病期診断と治療の目的で行なわれている. 血中マーカーの出現以前の成績も含め, 臨床的に Stage I と診断した症例の後腹膜リンパ節有転移率は $9 \sim 34 \%$ であり ${ }^{10) 11)}$, 後腹膜リンパ節廓清後の再発率 は10\%前後 ${ }^{12113)}$ となっている。放射線療法は主として 
英国，および我国に扔いて施行されてきた方法で，そ の再発率は10２0\% と報告されている ${ }^{8) 14}$.

最近の転移診断法の進歩, 化学療法の向上に伴って, 高位除睪術後に後療法を施行せず, 厳重な定期検査に より観察しょうとする意見もある。これは, Stage I 症 例の中に含まれる真の無転移症例に対し, 必要以上の 治療を避けるべきだとする考兵と, 転移診断法・化学 療法の進歩により早期に診断ができ, 転移が出現して からも化学療法にて治癒可能であるとする考光に基づ いている.

1984年，Johnson らは，31例の臨床的に Stage I の 非セミノーマ性辠丸腫瘍を後療法なしで 2 - 18力月間 (平均10力月) follow up し， 5 例に再発を認めたが, 26例は NED であり, 再発率は $16 \%$ であったと報告, さ らに, 再発した 5 例は全例, 化学療法にて CR に達した と述べている。また, Memorial Sloan-Kettering Cancer Center と Royal Marsden Hospital, 著者らの data 集計し，120例中 83 例は NED で観察中であり， 再発率は $18 \%$ であったと報告している。

当センターでは, 後療法は後腹膜リンパ節に対する 放射線療法を主体に施行してきた。しかし，放射線療 法のみで治癒できた症例は少なく，22年間を通じて 種々の試行錯誤をくりかえしてきた。35症例中24例に 後腹膜リンパ節に放射線療法を施行したが，14例 （58\%）は再発をきたした。再発部位は，10例（71\%） が肺転移であったが，1 例は鎖骨上窩リンパ節に， 3 例は照射部位中の後腹膜リンパ節であった。

当センターの集計より Stage I の症例に対する治療 を検討すると，放射線療法は諸家の報告に比べ再発予 防効果は認めがたく，再検討すべきであると考兄てい る、また，再発形式をみると，血行性転移が大部分を 占めることより，リンパ節に対する治療法のみでは不 充分で, 同様に予防的な後腹膜リンパ節廓清術は, Stage 診断の意義しか有さないと考えられる.

現在の診断技術の向上, 有効な化学療法の出現を考 えあわせれば, 転移巣の早期診断は可能であり, かつ 転移が出現してからの化学療法でも充分治癒可能と考 えられる由, Stage I 症例では, 除䁄術後に注意深い follow upをすることが最もよいのではないだろう か.

Stage IIa そついて

今回の集計で, Stage IIa は 4 例であったが, 1978年 以前の 2 例は, RPLND によりはじめて転移を確認で きたのに対し，1978年以降の 2 例は，1 例は AFPの下
降曲線より，1例はCT-scan，超音波断層法により診 断が可能であった。今後, 腫瘍マーカーの消長の注意 深い観察, CT-scan, 超音波断層法の導入により, Stage I と IIa の鑑別診断はさらに向上するものと考光られ る.

Stage IIa 症例の診断治療については, 後腹膜リンパ 節廓清術にて診断し, 術後化学療法を施行することが 定着している.

Stage IIa 症例に対する後腹膜リンパ節廓清術後の 再発率は $13 \%{ }^{14)} \sim 76 \%{ }^{15)}$ で， RPLNDのみでは治癒が 期待できないことを示している。それ故，RPLND と ともに化学療法が必要と考学られる。

Stage IIbについて

Stage IIb の診断は, 以前は理学的検査, リンパ管造 影と排泄性腎孟造影によりなされてきたが, 最近では, CT-scan, 超音波断層法が加わり，その診断はより容易 に, かつ正確になってきて抢り，問題はないと考兄ら れる。

Stage IIb 症例の治療については, Stage IIb と Stage III を含めて advanced case として取り扱らこ とが一般的であり, first choice として chemotherapy を施行するのが定着しつつある。

当センターでの治療は, 1978年以前の 8 症例中, 7 例は放射線療法を，1例は RPLND を first choice に 施行した。放射線療法を施行した 7 例中， 4 例に RPLNDを試みたが，手術可能であった症例は 1 例の みで， 3 例は生検に終っている，生検に終った 1 例は さらに腫瘍部に放射線療法を施行し，CR に至り生存 しているが，手術可能であった 1 例も含め， 3 例は死 亡した。をた, RPLNDを first choiceにし, 化学療法 を施行した 3 例はいずれも死亡し，全体として 8 例中 生存例は 1 例のみであった. (Table 3).

1978年以降の 2 例は化学療法を fimst choiceにし た. 1 例は, PVB 1コース後に RPLNDを施行, 腫 瘍組織は necrosisに陥っていた。また 1 例は, 他院治 療例で, CDDP, CDDP+VBLによる化学療法を施行, 術前 CDDP tatal 1,000mg 施行されていたが, 当セ ンターでの RPLNDでは腫瘍組織の变化は Grade IIa-change で viable cell が多数存在していた。

Stage IIb 症例の治療は, CDDPを含む充分な chemotherapyを1〜2コース施行後, RPLNDを施 行. 摘出標本の組織学的変化により, chemotherapy を 追加するのが適当と考学られる。

Stage III 症例にては言えることであるが， bulky 
tumor は chemotherapy にても完全に消失させるこ とは困難で, viable cell が存在し再発をきたすことが 多いため，手術療法は必須の条件と考㝋ている。

Stage III について

Stage III 症例の診断には, 理学的検查とともに, 腫 瘍マーカーの検索, 胸部 X-P, CT-scan, 超音波断層法 が必須である。特に胸部 CT-scan は, 縦隔リンパ節, 肺転移の有無の検索上, 胸部 X-P, 断層写真に比して すぐれており，診断のみならず治療効果判定の際にも 必須の項目と考兄られる。

Stage III の治療の主体が化学療法であることは, 現 在，議論の余地がないと思われる。

辠丸腫瘍の多剤併用による化学療法は，1960年，Li ら ${ }^{18)}$ とより施行された後, $\mathrm{VAB}^{3}$ 療法をへて, PVB療 法4), VAB-6 ${ }^{19)}$ などのすぐれた Regimen が開発されて きている。しかし，化学療法のみで治癒に至らない症 例があり，それらの症例の予後をいかに向上させるか が，現在の最大の問題点である。

今回の我々の集計でも，1978年以前の症例では，21 例中，治癒できた症例は 1 例のみで実測 5 年生存率 $4.8 \%$ と極めて不良であったのに対し, VAB 療法, PVB 療法を施行した1978年以降の13例では, 実測 3 年 生存率 $25.9 \%$ と治療成績の向上がみられた。しかし, $\mathrm{VAB}$ 療法を第 1 選択とした 5 例中 4 例，PVB 療法を 施行した 8 例中 7 例と，13例中 11 例 (84.6\%) に PR 以 上の効果を認めたにもかかわらず，CR に至った症例 は 1 例 (7.7\%) のみで, 化学療法の限界を認めた。

$\mathrm{VAB}$ 療法, PVB 療法の inducation therapy にて PRにとどまった10例中，手術を施行しなかった 7 例 は, さらにCDDPを中心にした化学療法, 放射線療法 を施行したが，いずれも CR には至らず腫瘍死したこ とにより, inducation therapy で PRにとどまる症例 はもはや化学療法のみでは治癒が期待できないと考 完, 残存腫瘍に対する積極的な手術療法が必要と考兄 ている.

化学療法と手術療法の関係については，充分な化学 療法にて腫瘍を切除可能, 寸なわち手術療法にて CR が期待できる程度にすることが必要と考光られる，症 例 2 では，転移巣が広汎であったため，手術療法を 2 回に分け切除する方針をとり, PVB 療法 2 コース施行 後, 後腹膜リンパ節廓清術, 縦隔リンパ節摘出術を施 行した。後腹膜転移巣, 縦隔転移巣の摘出は可能であっ たが，術後，肺転移巣の増大は著しく，2 回目の手術 は試験開胸に扔わった。PVB 療法を 4 コース施行後に
1 期的な手術療法を採用すべさであったと考兄られ た.

また, 症例 1 では, 後腹膜リンパ節転移移巣が巨大 で，摘出可能か否か判断できなかったため，手術は， 後腹膜リンパ節廓清術，左鎖骨上窩リンパ節～左腋窩 リンパ節廓清術, 縦隔リンパ節廓清術十右肺転移巣摘 出術と 3 回に分け施行した。本症例の残存腫瘍は mature teratoma であったため, 3 回の分割手術でも 治癒可能であったが, Embryonal carcinoma, choriocarcinoma を含み, かつ残存腫瘍に viable cell が存 在する症例では，何回かに分けた手術は危険であると 考兄られる。本症例では 1 回の手術で全ての転移巣が 摘出可能であり，充分に手術侵襲に耐えたと考えてい る.

症例 3 における治療が, 現在 Stage III 症例に対して 当センターで採用している方針である。すなわち, PVB 療法を $3 \sim 4$ コース施行後, 残存腫瘍に対する手 術を 1 期的に施行, 残存腫瘍の組織学的变化により, 化学療法を追加するか否かを判断する方針である。本 論文では，この結論に至るまでの大きな趗り道を苦い 反省をこめて正直に記したつもりである.

\section{結 語}

国立がんセンターにおいて，1962年より1984年 8 月 までに治療した成熟奇形腫を除く非セミノーマ性睪丸 腫瘍83例の治療成績を検討した。

1. Stage I 症例の後腹膜リンパ節への予防照射は, 再発率 $58 \%$ と再発予防効果は認めがたく，再発形成も 肺転移が71\% と血行性転移が大部分を占めていた。し かし，最近の診断技術の進歩により，より正確な病期 診断の向上，予後の向上が認められた。

2. Stage IIa の症例では, 後腹膜リンパ節廓清術と CDDPを含む化学療法が必要と考兄られた。

3. Stage IIb, III 症例では CDDP を含む化学療法を 第 1 選択とし, 残存腫瘍に対する積極的な手術療法を 施行し, その病理学的所見によって術後化学療法を施 行することが予後の向上の為には必須であると考兄ら れた。

<追補>

本論文中に用いられた薬剤名の略称

1) ACNU ; Nidran, b) Act-D ; Actinomycin-D, 3) ADR ; Adriamycin, 4) BLM ; Bleomycin, 5) CDDP ; Cis-diamminedichloroplatinum, 6) Ex ; Endoxan, 7) 5-FU ; 5-Fluorouracil, 8) IFO ; Ifosphamide, 9) MMC; Mitomycin-C, 10) MTX ; 
Methotrexate, 11) VBL; Vinblastine, 12) VCR ; Vincristine.

\section{文献}

1) 日本泌尿器科学会. 日本病理学会編：泌尿器科. 病 理. 辠丸腫瘍取扱い規約, 第 1 版, 金原出版, 東京, 1984.

2）大星章一, 下里幸雄, 板倉克明, 梅垣洋一郎: 癌放 射線療法の病理. 医学のあゆ久, 61, 618一625, 1967.

3) Carter, S.K. and Wasserman, T.H.: The chemotherapy of urologic cancer. Cancer, 36 , 729-747, 1975.

4) Einhorn, L.H. and Donohue, J.P.: Improved chemotherapy in disseminated testicular cancer. J. Urol., 117, 65-69, 1977.

5) Dosoretz, D.E., Shipley, W.V., Blitzwr, P.H., Gilbert, S., Prat, J., Parkhurst, E. and Wang, C. C.: Megavoltage irradiation for pure testicular seninoma. Cancer, 48, 2184-2190, 1981.

6) Mendenhall, W.L., Williams, S.D., Einhorn, L.H. and Donohue, J.P.: Disseminated semonoma: Re-evaluation of treatment protocols. J. Urol., 126, 493-406, 1981.

7）西尾恭規, 松本恵一, 大谷幹伸, 垣添忠生：殬丸精 上皮腫の治療成績。日本泌尿会誌，75，778-786, 1984.

8）河合恒雄, 桜木敏夫, 木原和徳：成人辠丸腫場の臨 㦿的検討. 第 1 部. HCG 陰性非セミノーマについ て. 泌尿紀要, 30, 627-637, 1984.

9）桜木敏夫, 木原和徳, 河合恒雄：成人辡丸腫煌の臨 床的検討. 第 2 部. HCG 陽性例について。泌尿紀 要, 30, 639-649, 1984.

10) Pissocaro, G., Durand, J.C., Fuchs, W.A., Merrin, C.E., Musumeci, R., Schmucki, O., Vahlensieck, W., Whitmore, W.F. Jr. and Zvara, V.L. : Staging and surgery in testicular cancer. Eur. Urol., 7, 1-10, 1981.

11) Clements, J.C., McLeod, D.G., Weisbaum, G.S. and Stutzman, R.E.: Radiation therapy for non-seminomatous germ cell tumors of the testis : A reappraisal. J. Urol., 126, 490-492, 1981.

12) Donohue, J.P., Einhorn, L.H. and Williams, S. D. : Is adjuvant chemotherapy following retroperitoneal LN dissection for nonseminomatous testis cancer necessary? Urol. Clin. North Am., 7, 747-756, 1980.

13) Fraley, E.E., Markland, C. and Lange, P.H.: Surgical treatment of Stage I and Stage II nonseminomatous testicular cancer in adults. Urol. Clin. North Am., 4, 453-463, 1977.

14) Tyrrell, C.J. and Peckham, M.J.: The response of Lymph node metastases of testicular teratoma to radiation therapy. Brit. J. Urol., 48, 363-370, 1976.

15) Johnson, D.E., Lo, R.K., von Eschenbach, A.C. and Swanson, D.W.: Surveillance alone for patients with Clinical Stage I nonseminomatous germ cell tumors of the testis: preliminary results. J. Urol., 131, 491-493, 1984.

16) Skinner, D.G.: Non-seminomatous testis tumors: A plan of management based on $96 \mathrm{pts}$ to improve survival in all stages by combined therapeutic modalities. J. Urol., 115, 65-69, 1976.

17) Maier, J.G., Van Buskirk, K.E., Sulak, M.H., Perry, R.H. and Schamber, D.T.: An evaluation of lymphadenectomy in the treatment of malignant testicular germ cell neoplasms. J. Urol., 101, 356-359, 1969.

18) Li, M.C., Whitmore, W.F., Golbey, R. and Grabstald, H. : Effects of combined drug therapy on metastatic cancer of the testis. J.A.M.A., 174, 1291-1299, 1960.

19) Vurgin, D., Herr, H.W., Whitmore, W.F. Jr., Sogani, P.C. and Golbey, R.B. : VAB-6 combation chemotherapy in disseminated cancer of the testis. Ann. Intern. Med., 95, 59-61, 1981. （1984年12月13日受付） 